\title{
THE DESIGN AND DURATION OF CONTRACTS: STRATEGIC AND EFFICIENCY CONSIDERATIONS
}

\author{
Scott E. Masten* and Edward A. Snyder $†$
}

\section{INTRODUCTION}

A vast body of economic theory is concerned with the way in which parties design contracts to align incentives and promote efficient exchange. ${ }^{1}$ An alternate view, however, ascribes to contract design a more sinister purposethat of excluding or otherwise disadvantaging rival firms. ${ }^{2}$ Although the latter argument has tended to target a specific set of suspect practices such as tie-in and exclusive dealing arrangements, recent efforts have begun to associate strategic objectives with more conventional pricing and incentive terms in contracts, including such common provisions as multi-part pricing schedules ${ }^{3}$ and stipulated damages clauses. ${ }^{4}$

In the course of developing and applying the antitrust laws, the courts have analyzed the effects of various contractual provisions on competition. The resulting body of law recognizes that contracts have the potential to exclude competitors but also that exclusion can serve efficiency purposes. ${ }^{5}$ The broadening of exclusion claims to include the strategic use of common contractual designs, and the corresponding potential to challenge a widely used class of contractual arrangements on antitrust grounds, stand to complicate rule-of-reason analyses of anticompetitive exclusion and raise

\footnotetext{
Copyright $(1989$ by Law and Contemporary Problems

- Associate Professor of Business Economics and Public Policy, University of Michigan School of Business Administration.

$\dagger$ Assistant Professor of Business Economics and Public Policy, University of Michigan School of Business Administration.

The authors would like to thank Deborah DeMott, Paul Godek, James Meehan, and participants at the conference and at seminars at the University of Michigan, the Antitrust Division of the Department of Justice, and the Federal Trade Commission.

1. For an overview of this literature, see Hart \& Holmstrom, The Theory of Contracts, in Advances in Economic Theory, Fifth World Congress 71 (T. Bewley ed. 1987).

2. See, e.g., Krattenmaker \& Salop, Anticompetitive Exclusion: Raising Rivals' Costs to Achieve Power over Price, 96 Yale L.J. 209 (1986). For a comparison of the strategic and efficiency views, see $O$. Williamson, The Economic Institutions of Capitalism: Firms, Markets, Relational Contracting 23-29 (1985).

3. Multi-part pricing refers to the use of a schedule of prices that vary with output.

4. See, in particular, Aghion \& Bolton, Contracts as a Barrier to Entry, 77 Am. Econ. Rev. 388 (1987)

5. See Broadcast Music, Inc. v. Columbia Broadcasting, 441 U.S. 1, $19-22$ (1979); Continental T.V., Inc. v. GTE Sylvania Inc., 433 U.S. 36, 54-56 (1977); Chicago Bd. of Trade v. United States, 246 U.S. 231, 238 (1918); United States v. Joint Traffic Ass'n, 171 U.S. 505, 560-61 (1898).
} 
broad public policy questions about the appropriate status of contracts in general. At a minimum, distinguishing situations in which contract provisions have strategic purpose from those in which such terms serve a more positive function becomes an important task.

Toward that end, this article begins by analyzing the efficiency and strategic roles of some common contractual provisions. In particular, we examine the assumptions underlying the results of both efficiency and strategic models of stipulated damage clauses and attempt to identify conditions conducive to using contracts for these conflicting purposes. Then, to gain insight into the practical motives and processes involved in designing contract terms and, particularly, to see whether there is evidence that these terms played a strategic role in actual settings, we examine a number of cases in which contracts involved stipulated damage or similar provisions affecting the incentives of a buyer to switch to an alternative supplier.

\section{II}

\section{Stipulated Damages and the Economics of Contracting}

The desire to design contract terms to promote efficient adaptation without the need for costly court intervention is the theme underlying most efficiency analyses of contracting. Given the substantial interval that often exists between the time a contract is entered into and executed, ${ }^{6}$ significant changes in the environment surrounding the transaction are likely to occur, requiring adjustments in the behavior of the parties. Because contracts that stipulate the optimal response of each party to each conceivable contingency are too costly to write and enforce, transactors tend to rely on a combination of common law rules and relatively simple, easily enforced contract clauses to accommodate change.

Among a number of common contractual arrangements that have been interpreted in this light are two-part pricing schedules, ${ }^{7}$ stipulated damage provisions, ${ }^{8}$ and minimum bill contracts. ${ }^{9}$ Each permits the quantity transacted under the contract to be adjusted in response to market conditions

6. Contract length varies with the nature and attributes of the transaction. Contracts extending ten years or more in length are common in some settings. Information on contract duration for particular industries and analyses of its determinants can be found in Joskow, Contract Duration and Relationship Specific Investments: Empirical Evidence from Coal Markets, 77 AM. ECON. REv. 168 (1987); Crocker \& Masten, Mitigating Contractual Hazards: Unilateral Options and Contract Length, 19 RAND J. Econ. 327 (1988); Goldberg \& Erickson, Quantity and Price Adjustment in Long-Term Contracts: A Case Study of Petroleum Coke, 30 J. L. \& ECON. 369 (1987). Also see the discussion of cases in Part IV of this article.

7. See, e.g., Goldberg \& Erickson, supra note 6.

8. See Shavell, Damage Measures for Breach of Contract, 11 Bell J. Econ. 466,470 n.14 (1980).

9. Masten, Minimum Bill Contracts: Theory and Policy, 37 J. Indus. Econ. 85 (1988); Masten \& Crocker, Efficient Adaptation in Long-Term Contracts: Take-or-Pay Provisions for Natural Gas, 75 AM. ECON. REv. 1083 (1985). More sophisticated contractual arrangements have been devised in the economic literature on contracting. See, e.g., Harris \& Townsend, Resource Allocation Under Asymmetric Information, 49 Econometrica 33 (1981). However, we are restricting our attention here to relatively simple pricing arrangements both to simplify the analysis and because they, unlike the more sophisticated arrangements, are commonly observed in practice. 
and, by relating the incremental price paid by the buyer to the seller's incremental cost, establishes incentives to respond efficiently. Moreover, compared to more elaborate arrangements, these schemes are easy to write and enforce, usually requiring only properly authorized orders and receipts to verify performance.

From an efficiency perspective, the reason transactors enter into long-term written contracts in the first place is to protect the relationship from strategic behavior in the form of either costly haggling over quasi-rents ${ }^{10}$ or free-riding on services or information provided by one of the transactors. The former problem arises where one or both parties have invested in reliance, or relationship-specific assets, in support of the transaction. ${ }^{11}$ Because such investments have a higher value in their intended use than in their next best use, parties have an incentive to engage in haggling or other forms of opportunism in hopes of influencing the distribution of the resulting quasirents. Contractual guarantees reduce the incidence of such behavior by restricting the ability of one party to extort concessions from the other by threatening not to perform. Free-riding, on the other hand, is a potential hazard, for example, where the cost of providing information or services associated with a purchase is included in the price of the product. If the unpriced service or information acquired from the original seller can be used with a competitor's product, the purchaser will have an incentive to avoid paying for the service by buying the product from a no-frills source. Contracts that restrict a purchaser's ability to use competing products can foster the development and provision of such services by suppliers. ${ }^{12}$

The notion that contracts are not deterrents to strategic behavior, but are instead strategic devices themselves, stands in sharp contrast to this view. Instead of constraining free-riding or haggling between the parties to an exchange, contracts are perceived as a means of restricting the actions of third parties, usually suppliers seeking to enter the market. Thus, those advocating a strategic view contend that two-part prices and stipulated damage provisions, instead of promoting efficient adjustment, establish entrance fees for rival firms, with the result that some low-cost firms are foreclosed from competing for business or deterred from entry.

In the remainder of this section, we examine how these competing theories interpret the use of stipulated damages. For purposes of analysis, stipulated damage provisions have the advantage of having received detailed attention from both the strategic perspective and the efficiency perspective, and also of being analytically tractable. The equivalence between stipulated damages and two-part pricing schemes in many settings also permits us to generalize our results to a broader class of contracts.

10. Quasi-rents refer to the excess of an asset's value in its current use over its next best use.

11. See, e.g., Klein, Alchian \& Crawford, Vertical Integration, Appropriable Rents and the Competitive Contracting Process, 21 J. L. \& Econ. 297 (1978); Shavell, supra note 8; Williamson, Transaction-Cost Economics: The Governance of Contractual Relations, 22 J. L. \& ECoN. 233, 245-54 (1979).

12. See, e.g., Marvel, Exclusive Dealing, 25 J. L. \& Econ. 1 (1982). 


\section{A. Stipulated Damages and Efficient Breach}

- In models of efficient breach, ${ }^{13}$ parties to a contract face uncertainty about some dimension of the transaction that makes it possible that actual performance will not in fact be desirable ex post. The uncertainty may be about the seller's costs, the buyer's valuation, or the availability of alternative buyers or sellers. ${ }^{14}$ The critical element is that in some situations the joint surplus between contracting parties may be larger if they do not perform the contract as originally intended.

Recognizing this possibility, the courts generally permit one party to discharge an obligation by compensating the other for lost profits. To see that the lost-profit or "expectation" measure of damages leads to efficient breach, consider a setting in which the buyer's valuation, $v$, and the supplier's cost of production, $c$, of a particular input are determinate, but there is uncertainty about the cost, $s(\theta)$, of acquiring supplies from an alternative source. If the cost of the alternative supplies falls below the price, $p$, agreed to in the contract (that is, $s(\theta)<p$ ) the buyer will wish to breach the contract with the original seller. Efficiency, however, requires that the buyer honor the contract with the original producer unless the cost of alternative supplies falls below the seller's opportunity cost, or $s(\theta)<c$. Thus, for values of $s(\theta)$ that fall between the original seller's costs and the contract price $(c<s(\theta)<p)$, the buyer will wish to breach even though breach is inefficient.

If the court sets damages, $\delta$, equal to the seller's lost profits in the event of breach, or $p-c$, then the buyer would be encouraged to perform the contract when it is efficient to do so. Specifically, the buyer would breach only if $v-s(\theta)-\delta>v-p$ or, equivalently, when $s(\theta)<p-\delta$. Setting damages, $\delta$, equal to the seller's lost profits would induce the buyer to breach when $s(\theta)<c$ (see Figure 1). As illustrated, the buyer is given the incentive to buy from the low-cost supplier, which is, of course, efficient.

\section{Figure 1}

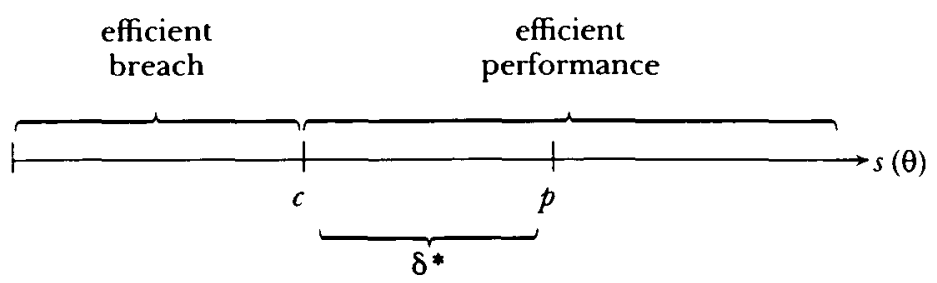

More important for the issue at hand, the level of damages that would maximize expected joint profits, were the parties to choose to stipulate

13. A now substantial literature in law and economics has developed on contract damages and efficient breach. See, e.g., Barton, The Economic Basis of Damages for Breach of Contract, $1 \mathrm{~J}$. LEGAL STUD. 277 (1972); Rogerson, Efficient Reliance and Damage Measures for Breach of Contract, 15 RAND J. ECON. 39 (1984); Shavell, supra note 8; Shavell, The Design of Contracts and Remedies for Breach, 99 Q. J. EcoN. 121 (1984). The model to be described most closely follows Shavell, supra note 8.

14. See Shavell, supra note 8 , at 474 . 
damages in the contract rather than rely on the courts, is also lost profits. ${ }^{15}$ The reason that parties might choose to stipulate damages is to avoid the costly process of establishing court-determined awards where the seller's costs may be difficult for the court to assess but are reasonably stable and recognized by the parties at the time they enter the contract.

The advantages of stipulating in advance a sum payable as damages are manifold. For both parties, it may facilitate the calculation of risks and reduce the cost of proof. For the injured party, it may afford the only possibility of compensation for loss that is not susceptible of proof with sufficient certainty. For society as a whole, it may save the time of judges, juries, and witnesses, as well as the parties, and may cut the expense of litigation. ${ }^{16}$

Finally, notice that the difference between the amount the buyer pays if the buyer performs the contract and the amount if the buyer breaches is $p-(p-c)=c$. In other words, expectation damages make the incremental cost of acquiring supplies from the seller equal to the seller's marginal cost. An equivalent way of writing the contract would be to adopt a two-part pricing schedule $^{17}$ stipulating a fixed component equal to the damage level identified above and a per-unit price equal to the seller's marginal cost. Hence, the generalization of the current analysis to that of two-part prices is straightforward.

Overall, circumstances in which there is (1) uncertainty about the buyer's alternatives and (2) relatively stable, though possibly unverifiable, costs of production are consistent with the efficient use of stipulated damages. As noted earlier, the desire to protect investments from free-riding or costly opportunistic haggling motivates the adoption of explicit contractual agreements in the first place. The duration of those agreements is likely to reflect the longevity of the investments and, where the distribution of rents is at issue, the degree to which the assets are specific to the relationship. ${ }^{18}$

\section{B. Stipulated Damages as a Barrier to Entry}

A recent article by Philippe Aghion and Patrick Bolton raises the possibility that contracts containing precisely the type of incentive provisions discussed above can be used strategically to create a barrier to entry. ${ }^{19}$ Indeed, the setting in which Aghion and Bolton develop their results is remarkably similar to the one associated with the efficient use of stipulated damages in the preceding section. ${ }^{20}$ Specifically, the costs of the incumbent seller, $c$, are determinate and known, as is the buyer's reservation price, $v$. But

15. This result is demonstrated in the Appendix, infra. See also Shavell, supra note 8.

16. E. FARnSWOrth, Contracts $\$ 12.18$, at 896 (1982).

17. Two-part pricing schedules combine an up-front fee and a per-unit charge. In our analysis, the buyer would pay $\delta=p-c$ whether or not he performed the contract and an additional per-unit charge, $c$, if he bought a unit of the good from the supplier. Hence, $\delta$ is equivalent to the fee component and $p-\delta$ (which equals $c$ ) is equivalent to the per-unit charge.

18. See Joskow, supra note 6, at 168-73; Williamson, Franchise Bidding for Natural Monopolies-In General and with Respect to CATV, 7 BELL J. ECON. 73, 79-91 (1976).

19. Aghion \& Bolton, supra note 4.

20. We examine in detail only one of two models contained in their paper. The second postulates contractual forms that, to the best of our knowledge, are not observed in practice. 
there is uncertainty about the $\operatorname{costs,} s(\theta)$, of acquiring supplies from an alternative source. Again, the parties face a choice of contract terms including the price and the level of damages to be stipulated in the contract.

Unlike the efficient breach models, parties in the strategic model optimally choose a damage provision in excess of the seller's lost profits. As a result, the buyer is induced to deal with the incumbent seller too often relative to the optimum, thereby deterring entry by the rival for a range of costs over which entry would be efficient. Thus, despite similarities in the underlying environment, damage provisions, rather than promoting efficient breach, serve as a barrier to entry.

A closer inspection of the Aghion-Bolton model reveals the source of this disparity. As in the efficient breach model, the seller receives $p-c$ when the contract is performed and $\delta$ when the buyer breaches. The buyer also nets $v-p$ when buying from the original supplier. But, unlike the previous model, the buyer cannot obtain supplies from an alternative source at their cost, $s(\theta)$, and instead pays a price above this level. The ability of the "entrant" to earn excess profits, that is, to set $p_{e}>s(\theta)$, creates the incentive for the original transactors to engage in strategic behavior. Since the new seller must charge a price below $p-\delta$ to induce the buyer to switch, stipulated damages determine the maximum price that the entrant can charge. Assuming the new supplier charges the highest price sufficient to induce the buyer to switch (i.e., $p_{e}=p-\delta$ ), the level of stipulated damages that maximizes the expected joint profits of the original contractors satisfies

$$
\delta=p-c+\frac{P}{P^{\prime}},
$$

where the probability of breach, $P$, is $\operatorname{Pr}[s(\theta)<p-\delta],{ }^{21}$ and $P^{\prime}$ is the marginal probability of $P$ with respect to a change in $p-\delta .{ }^{22}$

Thus the strategic model implies that the optimal penalty from the point of view of the parties is one that exceeds the lost profit measure by $P / P^{\prime} \cdot{ }^{23}$ Given a contract price, $p$, permitting some entry gives the seller a positive probability $(P>0)$ of receiving an amount in damages, $\delta$, greater than what the profits would be if the buyer performed, $p-c .{ }^{24}$ In designing the contract, the

21. The new seller will enter only if there exists a price, $p_{\ell}$, above his costs, $s(\theta)$, and below $p-\delta$, which will be true if $s(\theta)<p-\delta$. Hence, the probability of breach is $\operatorname{Pr}[s(\theta)<p-\delta]$.

22. See Appendix infra.

23. Note that the equilibrium price in the strategic model will be lower than in the efficiency model to compensate the buyer for the higher strategic penalties. The result of the strategic model is that, given the contract price, the penalty chosen will be at a level that will induce too little breach relative to the efficient level.

24. If the entrant's costs are uniformly distributed, damages would be set so that $\bar{s}$ is the average between the incumbent's costs, $c$, and the lowest possible value of $s(\theta)$. Those familiar with the literature on optimal auctions will recognize that the damage provision is set so that $p-\delta$ equals the optimal reserve price in an auction with symmetric bidders with independent private values. For an overview of this literature, see McAfee \& McMillan, Auctions and Bidding, $25 \mathrm{~J}$. ECon. Literature 699 (1987). Despite this correspondence, we doubt that many would advocate making the use of reserve prices in auctions or competitive bidding schemes an antitrust violation. 
original transactors trade off the gains foregone when an efficient entrant is excluded against the lower price the new supplier must accept when entry does in fact occur. The result is that the buyer is induced to switch to the alternative seller too infrequently relative to the social optimum (see Figure 2). Unable to supply the buyer, a rival with costs between $\bar{s}$ and $c$ is discouraged from entering.

\section{FIGURE 2}

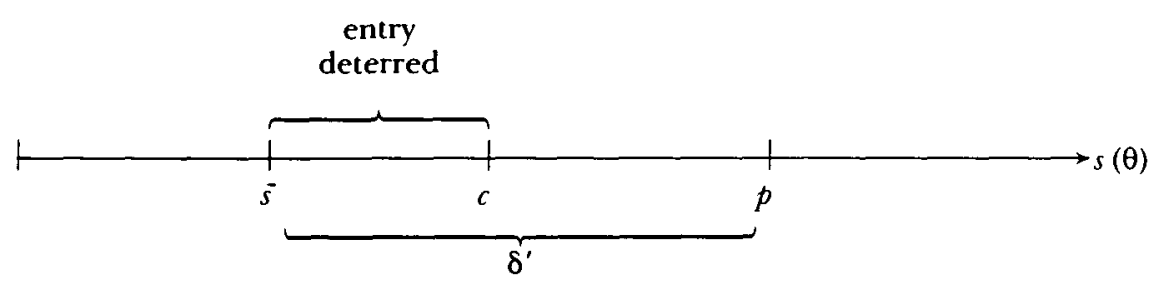

The role of contracts in the strategic model is to create an entry barrier that extracts part of the potential gains from trade from rival firms. Using damages, this extraction is accomplished by setting a penalty for breach in excess of the efficient level; with a two-part pricing schedule, the same effect is achieved by setting a per-unit price below the incumbent's marginal cost. The duration of contracts, meanwhile, is limited only by the desire of the incumbent to signal the probability of entry. An incumbent who perceives a high probability of entry will want protection by writing a longer-term contract, which the buyer will only agree to if the contract price is low; if the probability of entry is low, then the seller adopts shorter-term but higherprice agreements. ${ }^{25}$

\section{III}

\section{Requirements for the Strategic Use of Damage Provisions}

The source of the disparity in the results of the strategic and efficiency models of stipulated damages is readily apparent. Whereas the efficiency model presumes that new supplies are available at their true opportunity cost, the strategic model assumes the new supplier charges a price just sufficient to get the buyer to switch. In the latter case, the original transactors can extract some of the entrant's expected rents by stipulating "excessive" damage levels that "commit" the buyer to rejecting bids above $\bar{s}$. The potential inefficiency of excluding an entrant with costs between $\bar{s}$ and $c$ arises because the original transactors cannot discriminate between high-cost and low-cost entrants.

For this strategy to be successful, two factors are critical: (1) the contract must credibly commit the parties not to deal with the entrant except on the terms of the contract; and (2) the entrant must be able to earn positive economic rents by serving the customer, that is, the firm must expect to be

25. See Aghion \& Bolton, supra note 4, at 396. 
able to earn a return on its assets in excess of their value in their next best alternative use. This section evaluates these two requirements in turn.

\section{A. Commitment and the Law of Contracts}

The importance of commitment in the strategic model can be seen by examining the original transactors' optimal response to entry in the absence of a binding agreement. Before an entrant made a bid, the original transactors would have no specific information about the entrant's actual costs, leaving the parties in the position of a non-discriminating monopolist. ${ }^{26}$ Although it would be in the interest of the parties to announce their intention to reject bids below $\bar{s}$, once a bid was made the parties' incentives to accept or reject that bid would change. An entrant who met the transactor's reserve price would reveal, by this action, that the entrant's costs were no higher than $\bar{s}$ and were probably lower. The original transactors could exploit this information to appropriate a larger share of the entrant's expected rents by demanding further price concessions. On the other hand, if no bid were made, the original transactors would have an incentive to raise the minimum acceptable price. ${ }^{27}$

Thus, although a take-it-or-leave-it offer would maximize the expected profits of the original buyer and seller, their ex post incentive to alter the terms exposes the need for a mechanism to discourage deviations from the original terms. If take-it-or-leave-it offers lack sufficient commitment, then bargaining processes will determine between whom and at what price exchange will take place. ${ }^{28}$

The mechanism ostensibly serving to commit the parties to their best takeit-or-leave-it offer in the strategic model is contracting. Indeed, as long as the damage provision described in the model is enforceable, the buyer will be prevented from switching to the new supplier at bids above $\bar{s}$. Notice, however, that constraining the buyer's ability to accept price offers is not enough. Since the incumbent can avoid production costs, $c$, by procuring supplies from the lower-cost entrant, subcontracting produces gains whenever $s(\theta)<c$. Thus, for the contract successfully to deter entry, it must also limit the ability of the seller to deal with the entrant.

26. A "non-discriminating" monopolist (or, in the case of a single buyer, monopsonist) offers the same terms to all traders. According to the strategic model, the original transactors choose contract terms that do not take account of the entrant's actual costs. In contrast, a "discriminating" monopolist would set terms of trade that vary with known characteristics of other parties.

27. Lack of commitment raises a technical problem with the strategic model. Anticipating that the original seller and buyer have the incentive to take a stronger position once entry has taken place, no supplier would enter. But this is inconsistent with the parties' expectations that the original contract be profit-maximizing. Hence, unless the contract constrains not only concessions but also new demands on the part of the original contractors, the model does not have an equilibrium. We thank Naveen Khanna for bringing this point to our attention.

28. Reputation for adhering to such offers might assist an incumbent seller in its strategy, but several factors, including the infrequency of this type of interaction, suggest that reputation would not be a reliable source of commitment. In addition, the ability of the buyer to establish a reputation for integrating new supply sources would provide the buyer with a dominant strategy. 
A crucial issue then becomes whether contracts in fact serve the commitment function postulated in the strategic model. An examination of applicable laws governing contracts suggests that they may not. First, contracts generally permit a supplier to meet contractual obligations by offering substitute performance. The Uniform Commercial Code, for example, describes "both delegation of performance and assignability as normal and permissible incidents of a contract for the sale of goods." 29 Thus, the incumbent seller is normally at liberty to delegate performance or, alternatively, to procure supplies from a third party. ${ }^{30}$ In this respect, a contract can be thought of as mainly affecting who negotiates with the lowcost supplier, rather than whether such negotiation can take place. ${ }^{31}$

Second, the law confers on the parties to a contract the right to modify or rescind the terms of their agreement by mutual consent. ${ }^{32}$ By splitting the gains from dealing with the entrant three ways instead of two, the position of both parties to the contract can be improved relative to the status quo, satisfying a necessary condition for a modification to be negotiated and accepted. The incentive to renegotiate once an entrant has made a bid weakens the credibility of take-it-or-leave-it offers by the incumbents. Thus, even a "no substitute performance" clause is likely to fall to the ex post mutual interests of the parties.

Finally, although the common law gives the parties the latitude to stipulate damages, it is an established rule of law that damages must be reasonable " in light of the anticipated or actual loss caused by the breach."33 Stipulated damages in excess of this level are regarded as penalties and are therefore unenforceable. ${ }^{34}$ If the courts restrict damages to the efficient level, supply by the low-cost provider will occur no matter what share of the gains from trade can be commanded for the entrant's product. Thus, in principle, the common

29. U.C.C. $\$ 2-210$ comment 1 (1978). See also Restatement (SECond) of Contracts $\$ 318$ (1979) ("Delegation of Performance of Duty").

30. The principal exceptions to this rule relate to contracts for personal services and to contracts for the exercise of personal skill or discretion, and contracts in which delegation is prohibited by prior agreement. Even the latter may be voided if the terms are deemed contrary to the public interest. Restatement (Second) of Contracts $\$ 318$ (1979)

31. To the extent that contracts between automobile manufacturers and dealers restrict the ability of the dealers to carry competing manufacturers' products, American company dealings with low-cost foreign manufacturers are modest evidence of this practice.

32. See U.C.C. \$ 2-209 (1978).

33. Restatement (Second) of Contracts $\$ 356$ (1979).

34. The use of the terms "liquidated damages" and "penalties" reflects legal conclusions as to whether stipulated damages are reasonable. See U.C.C. $\$ 2-718$ comment 1 . The courts frequently rely on the principle that allowable damages to the seller correspond to the lost profits from breach. In David \& David, Inc. v. Myerson, 277 F. Supp. 973 (1966), the court found enforceable the requirement that a buyer take specified minimum quantities of a new product or reimburse the patent holder for any price reductions on sales to others. Similarly, in International Electronics Corp. v. United States, 646 F.2d 496 (Ct. Cl. 1981), the court upheld damages reasonably related to the costs imposed on the government from a seller's breach. For more information on the courts' treatment of liquidated damages, see generally Clarkson, Miller \& Muris, Liquidated Damages $v$. Penalties: Sense or Nonsense?, 1978 WIS. L. REv. 351 ; Rea, Efficiency Implications of Penalties and Liquidated Damages, 13 J. Legal Stud. 147 (1984); Rubin, Unenforceable Contracts: Penalty Clauses and Specific Performance, 10 J. Legal STud. 237 (1981). 
law would not support restrictions on even the buyer's ability to deal with a more efficient entrant.

In practice, of course, these common law impediments to strategic contracting do not make moot the issue of anticompetitive foreclosure. Challenging the legality of stipulated damages, like any legal action, is certain to impose some non-recoverable enforcement costs on the plaintiff. These costs include the obvious, such as witness time and attorney's fees, but may also include damages to the plaintiff's reputation that make other parties less willing to deal with the plaintiff in the future. The threat of such costs may deter a breaching party from filing suit to reduce damages. In addition, courts may choose to err in favor of the contract where the incumbent's costs are particularly difficult to ascertain, as is likely to be the case where damages were indeed stipulated for efficiency reasons. ${ }^{35}$ Nevertheless, several factors weigh against the survival of the penalty. First, the reality that strategic damages exceed lost profits where the provisions were chosen strategically favors the complainant in a trial of fact. Second, the savings to a buyer from dealing with a low-cost supplier provide the buyer with the incentive to seek relief from contractual penalties; the greater the inefficiency, the greater the gains to successful litigation and the larger the incentive to sue. Finally, litigation represents the last and probably least likely process through which to achieve a reduction in the penalty, given the mutual gains to a negotiated modification.

In sum, the ability to use contracts strategically may be undermined in any of several ways. The presumed legality of delegated performance, the illegality of penalties, and the potential for ex post agreements either to raise or to lower the entry fee all tend to undermine the credibility of the threat not to deal with the entrant except on the terms of the contract. In practice, the use of contracts as a barrier to entry must be accompanied by: (1) restrictions on the delegation of performance imposed by either the nature of the work or an explicit provision to prevent the seller from dealing with the entrant; and (2) high litigation and bargaining costs to prevent a legal or negotiated adjustment to the contract. Raising the costs of switching will deter some switching, but the resulting inefficiencies represent as much a failure in negotiations as market foreclosure. Indeed, the economic literature on incentive compatibility sometimes refers to the type of inefficiency generated

35. In deciding whether a stipulated damage clause is enforceable, the courts consider, in addition to the relationship between stipulated damages and anticipated or actual losses, two other factors: (1) the intent of the parties, and (2) the precision with which actual losses can be estimated. The courts try to ascertain whether the parties intended payment of damages in lieu of performance or intended that the damages would compel performance. If the court finds the latter, the damage provision is a penalty and not enforceable. See generally E. FARnsworTh, supra note 16 . Regarding the estimate of actual losses, the courts will not void a provision fixing liquidated damages "if the amount liquidated bears a reasonable proportion to the probable loss and the amount of actual loss is incapable or difficult of price estimation." Leasing Serv. Corp. v. Justice, 673 F.2d 70, 73 (1982); Truck Rent-A-Center, Inc. v. Puritan Farms 2nd, Inc., 41 N.Y.2d 420, 425, 393 N.Y.S.2d 365, 369, 361 N.E.2d 1015,1018 (1977). 
in the present model as a "cost of information," suggesting the irremediability of the problems identified by Aghion and Bolton. ${ }^{36}$

\section{B. Entry and Economic Rents}

In addition to these commitment requirements, the ability to use contracts strategically depends on the extent to which the damage provisions alter the entrant's price. The less power the entrant has to set price, the less the advantage in stipulating an excessive damage. To the extent, for example, that the buyer wields pure bargaining power to some degree over the new supplier, the incentive to use contracts for strategic purposes is mitigated. In the extreme, if the new supplier is unable to charge a price above marginal costs, the optimal damage becomes the efficient one. ${ }^{37}$ The latter situation would occur, for instance, if the uncertainty about $s(\theta)$ represented fluctuations in the price of a market substitute. In that case, competition would keep the entrant's price at marginal cost and thereby eliminate the incentive to design contracts strategically. ${ }^{38}$

In the Aghion-Bolton model, there is only a single entrant who has, in effect, full power to set price at the buyer's reservation value. This raises a basic question about the nature of entry. Since the entrant expects positive profits, why are other firms not attracted to the market? If the costs of entry are the same for all firms and it makes sense for one firm to enter, then it would also make sense for any firm. Competition for contracts to serve the buyer would guarantee that all expected rents accrue to the buyer.

For an entrant to expect an above-normal return, differential barriers to entry are required. ${ }^{39}$ In other words, the entrant must have a discrete advantage over other potential suppliers, generating the possibility of earning economic rents. If the source of that advantage also reveals the identity of the firm best situated to enter the market, however, the buyer has an incentive to integrate this supplier into the firm. By internalizing the rents accruing to "entry," such vertical integration eliminates the complicity of the buyer. At a minimum, the possibility of internalizing production limits the potential rents of an independent supplier.

In general, the existence of competition to supply the buyer undermines the possibility of using contracts strategically. In order for stipulated damages to serve strategic purposes, it is necessary to have some form of differential barrier to entry in addition to the commitment requirements discussed above. Even then, bargaining power on the part of the buyer reduces both the incentive to set excessive penalties and the amount of entry actually deterred.

36. See, e.g., Baron \& Myerson, Regulating a Monopolist with Unknown Costs, 50 EConometrica 911 (1982).

37. See Appendix infra.

38. This may be thought of as the scenario implicit in the efficient breach models.

39. See Aghion \& Bolton, supra note 4 , at 390 , for one explanation of why entry might be limited. 
IV

\section{Evidence of the Strategic Use of Damages}

A number of studies have examined actual contracting practices and offered plausible efficiency rationales for observed provisions. ${ }^{40}$ Studies scrutinizing contracts for strategic effect, however, are relatively scarce. To get a sense for whether the conditions necessary for strategic use of contracts are common in practice, we examined a sample of antitrust cases in which the design and duration of the contracts played a role. Such a sample is probably not representative of contracting practices in general, but, rather, is biased toward a finding of strategic effect.

Our search revealed only five reported decisions in which stipulated damage provisions or multi-part pricing schemes were alleged to exclude efficient rivals. ${ }^{41}$ The paucity of cases may reflect a variety of factors, one of which is the recent vintage of the literature on strategic use of these provisions. With respect to stipulated damages, the lack of enforceability of penalties may also be a significant factor. On the other hand, the infrequency may indicate that the underlying conditions required for anticompetitive exclusion to occur (the ability of entrants to earn positive profits, the reliance on non-discriminatory commitments by incumbents, the inability to verify the entrant's costs) are in fact uncommon.

Although the cases often involved additional concerns, in keeping with our preceding analysis, our discussion concentrates on whether the circumstances of each case permit a strategic interpretation of the contract provisions, or whether efficiency considerations (either investments in relationship-specific assets or free-rider problems) serve better to explain the use and design of the

40. See Crocker \& Masten, supra note 6, at 327; Goldberg \& Erickson, supra note 6; Joskow, Vertical Integration and Long-Term Contracts: The Case of Coal-Burning Electric Generating Plants, $1 \mathrm{~J} . \mathrm{L}$. Econ. \& ORG. 33 (1985); Joskow, supra note 6; Masten \& Crocker, supra note 9; Mulherin, Complexity in Long-Term Contracts: An Analysis of Natural Gas Contractual Provisions, 2 J. L. Econ. \& OrG. 105 (1986); Palay, Comparative Institutional Economics: The Governance of Rail Freight Contracting, $13 \mathrm{~J} . \mathrm{LEGAL}$ STUD. 265 (1984).

41. We searched all federal cases using Lexis to identify antitrust cases alleging exclusion due to either the use of stipulated damages, return fees, penalties, or multi-part pricing. The search revealed four disputes: United States v. United Shoe Mach. Corp., 110 F. Supp. 295 (D. Mass. 1953), aff'd per curiam, 347 U.S. 521 (1954); Barry Wright Corp. v. Pacific Scientific Corp., 555 F. Supp. 1264 (D. Mass. 1983), aff'd, 724 F.2d 227 (1st Cir. 1983); the IBM litigation concerning plug-compatible peripherals (Telex Corp. v. IBM Corp., 367 F. Supp. 258 (1973), aff'd in part, rev'd in part, 510 F.2d 894 (1975); ILC Peripherals Leasing Corp. v. IBM Corp., 458 F. Supp. 423 (1978), 636 F.2d 1188 (1980); California Computer Prod. v. IBM Corp., 613 F.2d 727 (1979)); and Broadcast Music, Inc. v. Columbia Broadcasting, 441 U.S. 1, $19-22$ (1979). We discuss these cases and two others: Automatic Radio Mfg. v. Hazeltine Research, Inc., 339 U.S. 827 (1950), which was cited by Aghion and Bolton, and a recently settled dispute between Citicorp and Western Union (Citicorp Servs., Inc. v. Western Union Tel. Co., No. 87-4463 (filed D. N.J.), complaint dated Nov. 9, 1987, answer and amended counterclaim filed by Western Union, Jan. 15, 1988). Note that our search procedure was not designed to identify cases involving either requirements contracts (e.g., Standard Oil v. United States, 337 U.S. 292 (1948)) or tie-ins (e.g., International Salt v. United States, 332 U.S. 392 (1947)). In addition, we note that reported decisions represent a non-random sample of cases, see Priest \& Klein, The Selection of Disputes for Litigation, $13 \mathrm{~J}$. LEGal STUD. 1 (1984), and so may not be representative of all complaints. In a similar vein, the rules against anticompetitive exclusion may suppress obvious instances of the strategic uses of contract provisions. 
agreements adopted. This analysis begins with a discussion in some detail of the case that in our judgment conformed most closely to the assumptions of the strategic model, Barry Wright Corp. v. ITT Grinnell Corp. ${ }^{42}$ We then examine the two cases offered by Aghion and Bolton as illustrations of their arguments, United States v. United Shoe Machinery Corp. ${ }^{43}$ and Automatic Radio Manufacturing Co. $v$. Hazeltine Research, Inc., ${ }^{44}$ and discuss relevant aspects of some related cases.

\section{A. Barry Wright Corp. v. ITT Grinnell Corp.}

Consistent with the strategic model, this dispute involved just three parties: Pacific Scientific Corp. ("Pacific"), which was an incumbent supplier of "mechanical snubbers" for nuclear power plants; ITT Grinnell Corp. ("Grinnell"), which made and installed nuclear plant pipe systems and was Pacific's major customer; and Barry Wright Corp. ("Barry"), which sought to enter the business of producing mechanical snubbers. ${ }^{45}$ Until 1975 most snubbers, which act as shock absorbers for pipe systems, were hydraulic. At that time, architects and engineers for nuclear plant manufacturers began to specify mechanical snubbers, due to leakage problems with hydraulic units. ${ }^{46}$ Only Pacific's mechanical snubber received Nuclear Regulatory Commission approval, making Pacific an effective monopolist in the late 1970's. ${ }^{47}$

At about the time that Barry entered the picture, Pacific offered Grinnell price discounts if Grinnell would agree to long-term contracts containing implicit cancellation penalties. Specifically, in the fall of 1976, Pacific offered Grinnell additional 5 percent and 10 percent discounts ${ }^{48}$ on its product if Grinnell would sign contracts specifying large dollar orders. Grinnell was not prevented from purchasing additional units from other suppliers, but the record shows that the dollar amounts approached Grinnell's expected needs. In addition, the contract contained a clause, which was at the center of Barry's claims, requiring Grinnell to purchase from Pacific 100 percent of the dollar amounts stipulated in the contract.

In January of 1977, Grinnell and Pacific agreed to a one-year contract for $\$ 4.3$ million; in May of that year, they signed two additional one-year agreements stipulating purchases of $\$ 6.9$ million in 1978 and $\$ 5$ million in 1979. The 1977 discount prices applied for the first two years, with an inflation adjustment for the final year. Barry, the would-be entrant, brought suit against Pacific and Grinnell, arguing that the price cuts offered by Pacific

42. 724 F.2d 227 (1st Cir. 1983); see supra note 39.

43. I10 F. Supp. 295 (D. Mass. 1953), aff'd per curiam, 347 U.S. 521 (1954).

44. 339 U.S. 827 (1950).

45. Barry Wright Corp. v. Pacific Scientific Corp., 555 F. Supp. 1264, 1265-66 (D. Mass. 1983). A discussion of this case can also be found in Williamson, Pretrial Uses of Economists: On the Use of

"Incentive Logic" to Screen Predation, 29 Antitrust Bull. 475 (1984).

46. Barry Wright, 555 F. Supp. at 1265-66.

47. Id. Its share of mechanical snubber sales was $94 \%$ in 1979. Barry Wright, 724 F.2d 227, 229

(1st Cir. 1983).

48. Pacific's standard rate was $20 \%$ off list price; it offered an extra 5 or $10 \%$ off list. Barry Wright, 724 F.2d at 229. 
were predatory and that the cancellation clause was exclusionary. In particular, Barry argued that the cancellation provisions compelled contract performance and, except to the extent that Grinnell's needs exceeded the dollar amounts specified in its contract with Pacific, effectively excluded Barry.

Although on the surface these facts fit the Aghion-Bolton scenario, the record reveals important details that bear on the nature and purpose of the contracts. First, the history of the relations among the parties and their behavior provides a rich example of real-world bargaining. In particular, Grinnell's actions prior to signing the contracts with Pacific show clearly that Grinnell was not a passive buyer whose agreements with Pacific were intended to exclude Barry as a second source. On the contrary, Grinnell was an active participant in Barry's efforts to produce mechanical snubbers.

As noted earlier, Grinnell became a major customer of Pacific when the market turned from hydraulic to mechanical snubbers. During this period, Grinnell attempted to develop its own snubber production capability, ${ }^{49}$ but, having failed at these attempts, sought to have Barry, which had previously produced a mechanical snubber prototype for aerospace applications, manufacture snubbers for Grinnell's use. Indeed, the terms of the agreement between Grinnell and Barry resembled a joint venture. ${ }^{50}$ Grinnell agreed to pay up to $\$ 294,000$ of Barry's development costs and to buy snubbers exclusively from Barry, committing itself to between $\$ 9$ and 15 million worth of purchases in the period between 1977 and 1979.51 According to the agreement, Barry would sell only to Grinnell for this period and left Grinnell the option to buy Barry's production facilities within the three-year period.

Only when it became evident that Barry would not be able to meet its contractual obligations did Grinnell open negotiations with Pacific to meet its snubber needs. Furthermore, even though it was clear early on that Barry could not qualify its products by January 1977, Grinnell rejected Pacific's initial offer of price discounts tied to placing a $\$ 5.7$ million order to cover its 1977 requirements. Instead, Grinnell placed a $\$ 1$ million order at the usual, undiscounted price. Barry continued to have production problems and in January 1977 signaled to Grinnell its inability to deliver small units until August 1977 and larger units until February 1978. Grinnell informed Barry that Barry had breached their earlier agreement and subsequently entered into the three contracts with Pacific that assured Grinnell of the discount prices through 1979.52

Contrary to the strategic model, the facts in this case reveal that the buyer (Grinnell) had substantial bargaining power in its dealings with both the incumbent (Pacific) and the entrant (Barry). Indeed, the record indicates that the negotiations took place in an ongoing fashion, with no party relying on

49. Grinnell had been a major producer of hydraulic snubbers. Barry Wright, 555 F. Supp. at $1264-66$.

50. Reflecting the character of the Grinnell/Barry agreement, Grinnell internal correspondence referred to it as such. Id. at 1270 .

51. Id. at 1266.

52. Id. at 1268-69. 
non-discriminatory final offers. Moreover, attempts to enter the industry came either directly from Grinnell or with Grinnell's direct participation. In paying Barry's development costs and stipulating per-unit prices ex ante, Grinnell assured itself prices at or near Barry's marginal costs. Under such circumstances, it is unlikely that Grinnell would have acquiesced to contracts designed to extract the surplus from that arrangement, which accrued mainly to itself.

Second, it appears that the contract generated cost savings for Pacific. The production of snubbers involved lags of about six months between orders and delivery. The court record establishes that Pacific realized substantial economies from being able to rely on a high level of production: "The price discount, by securing the firm order, allowed Pacific to operate [at] this capacity more efficiently, saved Pacific money, and thereby produced more profit than a higher price (without the firm order) could have done, without regard to any impact on Barry." 53 Nor did the duration of the contracts seem excessive in light of these lags and the small-numbers negotiating setting in which they were written. ${ }^{54}$ Grinnell's exhibited reluctance to enter the contracts with Pacific was eroded only as it became increasingly evident that Barry would not become a viable second source. In fact, Grinnell agreed to large-volume, long-term agreements with Pacific only after it had become unmistakably clear that Barry would be unable to produce an acceptable substitute within any reasonable period.

An additional consideration was the nature and effect of the cancellation clause in the contract between Grinnell and Pacific, which was a matter of dispute among the litigants. While Barry claimed the clause required Grinnell to pay for 100 percent of its obligations to Pacific upon cancellation of the contract, the district court concluded:

[I]t is clear that blanket purchase orders of the type executed by Pacific and Grinnell in January and July, 1977, were agreements governing price only. No firm obligations of the seller to deliver and the buyer to pay for the good arose until specific purchase orders were submitted. If the agreed upon minimums were not ordered, the agreed upon discounts would be withdrawn, and the purchaser would be obligated to pay at standard rates for products actually ordered and delivered. ${ }^{55}$

If this interpretation of the cancellation provisions of the contract is correct, the effective penalty for reducing orders, and thus the contract's potential for exclusion, is substantially lessened. For the incentive provisions of the contract to exclude a more efficient rival, the effective contract price

53. Barry Wright, 724 F.2d at 236.

54. District Court Judge Skinner concluded:

It seems to me to be an extraordinary extension on [sic] antitrust theory to hold a noncancellable clause in a one-year purchase contract illegal because [fulfillment is] not economically inevitable. I have found no case so holding, and I rule that the imposition of this clause, given the history of the relations between Grinnell and Pacific, and Pacific's legitimate desire to plan its production for at least a year, is not illegal exclusionary conduct

Barry Wright, 555 F. Supp. at 1272.

55. Id. 
would have to be below the marginal costs of the incumbent. Whereas a 100 percent minimum bill requirement would have satisfied that condition, the volume-based quantity discounts left price substantially above marginal costs over all but a 5 to 10 percent range of the contract minimum. ${ }^{56}$

Although the cancellation provisions in this case were held to be nonexclusionary, the appellate court underscored the general point that even if Pacific did try to use the cancellation clause to compel performance, the provision would represent a penalty and would not be enforceable. ${ }^{57}$ The court acknowledged the concern that the provision's "presence does still threaten the buyer with the lawsuit that would be needed to prove that it is unenforceable. And it is this threat, and the consequent additional deterrence to the 'breach and pay damages' course of action that constitutes the 'unreasonable anticompetitive' aspect of the clause." 58 But the court found this argument to be inapplicable in this case: "Given Grinnell's size and the competence of its legal staff, it is most unlikely to have been deterred by Pacific's assertion of unusually high damages resting upon a legally invalid provision in the contract." 59

When examined in detail, Barry $v$. Grinnell serves, in our opinion, to demonstrate a number of the obstacles to using contracts strategically and the hazards of entertaining claims of exclusion based on contract damages. A buyer facing a sole supplier has considerable incentive to promote development of alternative sources, through either outside suppliers or integrated production and, as long as those prospects remain viable, would be understandably reluctant to commit itself to dealing with an incumbent supplier for an extended period. The analysis also reinforces the tenuous legal status of the terms needed to support exclusion. Parties have an incentive to challenge, and courts frequently invalidate, cancellation provisions perceived to penalize the breacher. Finally, the case between Barry and Grinnell effectively illustrates the potential for abuse of the antitrust laws by opportunistic agents. ${ }^{60}$ The prospect of treble damages was enough to induce a clearly high-cost rival like Barry to file against its former partner.

56. The court found the discounted prices "generated revenues more than sufficient to cover the total cost of producing the goods to which they applied," a finding that Barry did not dispute. Barry Wright, 724 F.2d at 231.

57. The appellate court stated:

Even if one heroically assumed that Grinnell might have wished to breach and to buy elsewhere in 1977,1978 or 1979 , it is virtually impossible to believe that the presence of this clause could have stopped it from doing so. Given Grinnell's size and the competence of its legal staff, it is most unlikely to have been deterred by Pacific's assertion of unusually high damages resting upon a legally invalid provision in the contract. (And, if the provision is not legally invalid-that is, if it does reasonably reflect Pacific's likely actual damages-then it is not, from an antitrust perspective, unreasonable.)

Id. at 239.

58. Id.

59. Id.

60. For a discussion of the problems ensuing from the availability of the private antitrust remedy to competitor plaintiffs, see E. Snyder \& T. Kauper, Misuse of the Antitrust Laws (University of Michigan Working Paper, 1989). 


\section{B. United States v. United Shoe Machinery Corp.}

Cited by Aghion and Bolton as an illustration of their argument, ${ }^{61}$ United Shoe is the most famous antitrust case involving the use of contract provisions to deter customers from switching suppliers. ${ }^{62}$ United, the dominant manufacturer of shoe machinery in the 1940's and 1950's, ${ }^{63}$ leased its machines under long-term contracts that included three potentially suspect provisions: (1) minimum monthly fees; ${ }^{64}$ (2) a "full capacity clause" requiring lessees to "use the leased machine to its full capacity upon all boots, shoes, or other footwear or portions thereof . . of which such machine is capable of being used;" 65 and (3) substantial fees for returning machines during the term of the lease, which usually ran ten years. ${ }^{66}$

Although the government succeeded in convincing the court that these provisions combined to deter switching to United's competitors, three factors raise doubts that United's leases would have excluded an efficient entrant and lend support to an efficiency interpretation of the provisions. First, the necessary condition that entrants stood to earn above-normal rates of return was probably absent. In fact, United faced competition for decades from a group of competitors properly characterized as a competitive fringe. ${ }^{67}$ These firms typically did not engage in research and development efforts, did not innovate, and competed by offering similar machines. ${ }^{68}$

61. Aghion \& Bolton, supra note 4 , at 388 .

62. United States v. United Shoe Mach. Corp., 110 F. Supp. 295 (D. Mass. 1953), aff'd per curiam, 347 U.S. 521 (1954). We plan to analyze United Shoe's practices and the effects of the antitrust litigation in more detail in future research. For a detailed review of United Shoe, see C. KAYSEN, United States y. United Shoe Machinery Corporation: An Economic Analysis of an ANTi-trust CASE (1956). Posner cited United Shoe to illustrate his claim that suppliers must compensate customers for exclusionary contract provisions: "[C]ustomers of United would be unlikely to participate in a campaign to strengthen United's monopoly position without insisting on being compensated ..." R. Posner, Antrtrust Law: An Economic Perspective 203 (1976). However, for reasons articulated by Aghion and Bolton, the strategic argument must be evaluated on its merits.

63. United's dominance dates back to industry consolidation in 1899 and some 30 subsequent acquisitions. United Shoe, $110 \mathrm{~F}$. Supp. at 307, 312.

64. The effect of the minimum monthly fee was to lower the implied marginal cost of using a machine at operating levels below 25 percent of capacity. Id. at 319-20.

65. Id. at 316 .

66. Id. at 316-17. United leased most of its machines, a practice that may reflect its customers' preferences, as leasing made it "easy for a person with modest capital and of something less than superior efficiency to become a shoe manufacturer." Id. at 323 . But, as is well understood, by leasing, a manufacturer retains control over the secondary market and as a result may be better able to exploit its demand. In support of this view, the record cites that United purchased used machines only to dispose of them. Id. at 333-34 (from 1931 to 1942 , United spent approximately $\$ 350,000$ for used machinery that apparently was not resold or leased).

67. Carl Kaysen states:

Existing rivals in the machinery market do not appear to constitute a significant limitation on United's power. The sample of shoe factories revealed 22 known competitors, the largest of which was Compo, with 3.4 per cent of the total number of major machines in the sample inventory and the second largest, International Shoe Machinery Corp., with 0.6 per cent of the total number of machines.

C. KAYSEN, supra note 62, at 52. United Shoe's dominant market position was due to a combination of numerous acquisitions and mergers and internal growth, as discussed briefly by the district court, United Shoe, 222 F. at 349, and in more detail in C. KAYSEN, supra note 62.

68. The district court stated that while United Shoe had over 2000 patents for shoe machinery equipment, most of its important patents had expired. United Shoe, $110 \mathrm{~F}$. Supp. at 332-33. The 
Second, the substantial return fees charged by United are consistent with non-strategic motives. Without any return fees, a customer would wish to return the machine whenever the lessee's valuation fell below the stream of payments required to keep the machine. United, however, would want to discourage returns unless a customer's valuation fell below United's opportunity cost. Given United's market power, the alternative value of a returned machine would have been United's marginal revenue-which would have been equated (in expected terms) to its marginal cost-rather than the rental price. ${ }^{69}$ Thus, even absent strategic intentions, United would have set a return fee equal to the premium in excess of its marginal costs.

Lastly, when a manufacturer provides information or services that are not specific to the manufacturer's product, a buyer may be able to avoid payment for the services by switching to a competitor's product, jeopardizing the provision of the services. The existence of free-riding of this sort has been used elsewhere to justify exclusive-dealing arrangements. ${ }^{70}$ In the present case, United offered an extensive network of information and services to its customers in conjunction with its machines, much of which was of a type that could be valuably employed in conjunction with non-United equipment. ${ }^{71}$ Moreover, given that most of United's important patents had expired, ${ }^{72}$ United was particularly vulnerable to offerings of similar machines by its competitors who did not provide similar levels of support and service. In light of this situation, switching fees may have represented a less extreme alternative to exclusive dealing as a response to the problem of free-riding on manufacturer services.

median age of United Shoe's models was 28 years in 1953, and its more important models tended to be even older. Id. at 331. Given the absence of patent protection, competitor machines were available for all key steps in the manufacturing process. Id. at 339. Although strategic lease provisions could account for the failure of firms within this fringe to attract substantial numbers of customers from United Shoe, the ability of United Shoe to deny an outlet for its competitors' machines is disputed by the existence of some 1400 shoe manufacturers in the industry at that time. Id. at 301,328 . The ability of competitors to find potential outlets for their machines was further enhanced by a turnover rate of $10-12 \%$ per year in the shoe manufacturing industry. C. KAYSEN, supra note 62 , at 55 .

69. Cf. Ryder Truck Lines, Inc. v. Goren Equip. Co., Inc., 576 F. Supp. 1348 (N.D. Ga. 1979). In this case concerning the sale of used diesel engines, the court found that a stipulated damage clause requiring the buyer to pay the full contract price in the event of breach was unenforceable since "had plaintiff repossessed the unpaid engines, it would have had the option of reselling those engines in an attempt to 'cover,' and it would be able to recover the difference between the resale price and the contract price." Id. at 1357. The issue of Ryder's market power was not addressed. Given that shoe machines, like diesel engines, are not specialized assets and therefore have a high alternative value, the same reasoning could be applied to United's return fees. Note, however, that placing of a used machine could require some discounting due to a "lemon's effect."

70. See, e.g., Marvel, supra note 12.

71. The service included expert advice on how to improve the quality of shoe production, help in various technical shoemaking and shoe factory problems, and technical assistance to "shoe manufacturers desiring engineering surveys on production methods, on costs, on factory layouts, and other matters." United Shoe, 110 F. Supp. at 321.

72. Id. at 333. For a discussion of United's patents, see C. KAYSEN, supra note 62, at 78-90. 
C. Automatic Radio Manufacturing Co. v. Hazeltine Research, Inc.

In addition to United Shoe, Aghion and Bolton cite one other case, Automatic Radio Manufacturing Co. $v$. Hazeltine Research, Inc. In this case, defendant Hazeltine, a developer of radio broadcasting technology, allowed its licensees to use any or all of Hazeltine's current and future patents in return for royalties equal to a small percentage of the licensee's gross sales. At the time of the litigation, the license covered 570 patents and 200 applications used in the manufacture of radio broadcasting apparatus. ${ }^{73}$

Aghion and Bolton argue that licensees such as Automatic Radio "had to pay a fixed fee irrespective of whether it exploited the patents licensed" and that "[a]ny new licensor therefore faced an entry barrier equal to the amount of this fee."74 More precisely, a bias against using competitors' patents would arise because of differences in the marginal cost of adopting the alternative technologies. Since the fees paid to Hazeltine were a function only of the manufacturer's sales, the marginal cost of using an additional Hazeltine patent to a manufacturer who already used a Hazeltine technology was nearly zero; whereas to adopt an alternative technology, a manufacturer incurred a cost equal to the amount charged by the alternative licensor.

However, each court that reviewed the case expressed the view that charging fees equal to a percentage of licensee sales reflected sound business judgment. ${ }^{75}$ Requiring Hazeltine to charge for each use of its hundreds of patents would have decreased the value of Hazeltine's patents (1) by substantially increasing monitoring costs, and (2) by discouraging use of the patents at the margin by increasing the cost of output embodying the patented technologies relative to that of other output. ${ }^{76}$ Since the actual cost of extending the use of a patented technology to an additional application is negligible, the efficient use of that technology dictates a zero incremental cost to the user. Thus the license terms appear to have given licensees the correct incentives to utilize Hazeltine's patents fully while minimizing the costs of collecting royalties. ${ }^{77}$

\section{Other Cases}

Two additional cases serve further to illustrate the difficulty of imputing strategic motives to contractual agreements. The first regards a recently

73. 339 U.S. 827,829 (1950).

74. Aghion \& Bolton, supra note 4 , at 398.

75. Hazeltine Research, Inc. v. Automatic Radio Mfg. Co., 77 F. Supp. 493, 496-97 (D. Mass. 1948); 176 F.2d 799, 804 (1st Cir. 1949); 339 U.S. 827, 834 (1950).

76. 339 U.S. at 833; 176 F.2d 799, 804 (1st Cir. 1949); 77 F. Supp. 493, 496 (D. Mass. 1948). The cost of monitoring usage of patented or copyrighted material was also the basis for justifying ASCAP's and BMI's use of blanket licenses for rights of all musical compositions in their repertories in exchange for flat annual fees. See Broadcast Music, Inc. v. Columbia Broadcasting, 441 U.S. 1 (1979).

77. In addition, licensees were not otherwise compelled to adopt the inventions covered by the patents or restricted from producing goods using other patents. Id. 
settled dispute between Citicorp and Western Union, ${ }^{78}$ and the second relates to the role of license fees in litigation over IBM's leases for plug-compatible peripheral components. ${ }^{79}$

The dispute between Citicorp Services, Inc, and Western Union Telegraph Co. offers another example of the use of "exclusionary" contracts to protect against free riding by an entrant on manufacturer-provided services. Attempting to establish itself in the "public money transfer" business, Citicorp had enlisted Western Union agents to act also as Citicorp agents, offering commission rates above Western Union's as an inducement. In response, Western Union: (1) imposed exclusive dealing contracts on some of its 10,500 outlets; (2) terminated some outlets that agreed to act as Citicorp agents; and (3) denied other dual agents the right to handle other Western Union services.

Although Citicorp alleged that these actions prevented it from entering the money transfer market, the actions can be interpreted as consistent with the manufacturer-services rationale for exclusive dealing and switching penalties. In establishing an effective network, Western Union needed to identify suitable agents and locations over an extensive geographic region, as well as advertise the existence and qualities of its service. Quite clearly, Western Union was vulnerable to free riding on its efforts to attract customers and agents, if the latter were also allowed to offer Citicorp services. By relying on Western Union's advertising and locations, Citicorp could lure away both customers and agents with more favorable terms without incurring comparable costs.

The IBM litigation focused on IBM's announcement in May of 1971 of its fixed-term leasing plan for plug-compatible peripherals. Several rivals objected to IBM's reductions in rental rates and to their new one- and twoyear leases. The leases offered discounts of up to 10 percent on monthly rates and imposed return fees that in the two-year leases, for instance, equaled five times the monthly rental if the lease was terminated in the first twelve months, and two and one-half times that amount in the second year. ${ }^{80}$

Again, the facts of the case make it difficult to impute a strategic motive to IBM. First, the leases were introduced after several competitors had already established themselves in the peripheral market and in response to significantly lower prices by the entrants. ${ }^{81}$ IBM's lease terms themselves were similar to the terms offered by competitors and, according to the courts involved in this litigation, were commonplace commercial agreements. ${ }^{82}$

78. Citicorp Servs., Inc. v. Western Union Tel. Co., No. 87-4463 (filed D. N.J.), complaint dated Nov. 9, 1987, answer and amended counterclaim filed by Western Union, Jan. 15, 1988.

79. Telex Corp. v. IBM Corp., 367 F. Supp. 258 (1973), aff'd in part, rev'd in part, 510 F.2d 894 (1975); ILC Peripherals Leasing Corp. v. IBM Corp., 458 F. Supp. 423 (1978), 636 F.2d 1188 (1980); California Computer Prod. v. IBM Corp., 613 F.2d 727 (1979).

80. Telex, 510 F.2d at 902-03.

81. Id. at 903-04.

82. Telex Corp. v. IBM Corp., 367 F. Supp. 258, 300-01, 346 (Court Finding F100 and Court Conclusion $\mathrm{C29}$ ). These findings are cited and discussed at length by the appellate court in $T e l e x$, 510 F.2d at 906, 920-21. 
Moreover, by using longer leases, IBM, like its competitors, avoided costly "churning" of machines and succeeded in reducing its costs. ${ }^{83}$

Perhaps more important, the IBM case illustrates the potential for misuse of the private antitrust remedy that could arise if theories of exclusion based on the use of contract provision were generally accepted. Such theories would allow competitor plaintiffs who were "excluded" merely because of competition to bring Sherman Act section 2 claims. Even if the courts eventually reject meritless claims of exclusion, the costs of applying rule-ofreason analyses to the questions of strategic use of contracts could restrict incumbents' responses to entry and, perversely, could sustain entry by less efficient suppliers. Thus, establishing antitrust liability based on the strategic model would involve a tradeoff between exclusion of more efficient entrants and restrictions on more efficient incumbents.

\section{V}

\section{CONCLUSION}

The conditions under which contracts can be used strategically are fairly restrictive. First, a new supplier must expect to earn excess rents upon winning the customer's business. Where the market for substitute performance is populated with homogeneous firms, competition among them to serve the buyer keeps price near marginal costs, eliminating the strategic motive of the original contracting parties. For there to be expected rents from entry, some firms must be substantially better situated to enter than others. Even then, the possibility of integrating the low-cost supplier reduces the threat of strategic deterrence. Finally, there is both theoretical support and casual evidence for the contrary conclusion that buyers, if anything, are likely to maintain even inefficient producers as second sources to gain leverage in bargaining with incumbents. ${ }^{84}$

When the economic conditions for the strategic use of contracts are present, the law presents a number of obstacles to deterring entry through contracts. First, the common law treatment of excessive damages undermines directly the ability of parties to use contracts strategically. In addition, rules regarding delegation of performance and mutual modification mitigate, if not eliminate, the commitment required to prevent the parties from striking deals, either unilaterally or in concert, with a more efficient supplier. In these respects, at least, the law of contract supports efficient outcomes. Indeed, the results of the Aghion-Bolton model provide an additional reason not previously identified in the literature for why court invalidation of contract penalties is a sensible legal precept. ${ }^{85}$

83. Telex, 367 F. Supp. at 297, 300-01 (Court Findings F89a and F100); 510 F.2d at 920-21.

84. See, e.g., Demski, Sappington \& Spiller, Managing Supplier Switching, 18 Rand J. ECON. 77 (1987).

85. Aghion \& Bolton, supra note 4, at 389-92. 
Our review of antitrust cases relating to the issue of contract exclusion further supports a cautious approach to exclusionary claims. Despite a presumptive bias toward a finding of strategic effect, the small set of cases that deal with exclusion through use of stipulated damages or their equivalent fails to substantiate the purported dangers of exclusionary contracts. Often, behavior or conditions necessary for successful exclusion are absent. The record of dealings in Barry Wright, for instance, illustrates the process of complicated negotiations and rivalry that often characterizes small-number supplier-customer relations-and contradicts the take-it-or-leave-it contract commitment essential to the theory. In every case, moreover, the contract provisions in question have sound efficiency rationales.

What stance should the antitrust laws take toward stipulated damage and related contractual provisions in light of these findings? A central question is whether the courts can devise market tests or screens to identify when contract provisions are likely to be used strategically and when they enhance efficiency by properly aligning incentives. ${ }^{86}$ Even if such tests can be developed, whether courts should subject such provisions to a rule-of-reason analysis as a general policy depends on the costs of applying the rule, both in terms of enforcement and in terms of the impairment of efficiency. The inclination of firms to use the antitrust treble damage remedy to impose costs on rivals suggests that a substantial threshold should be established before provisions, widely recognized to enhance efficiency in many circumstances, are exposed to critical legal review because of conceivable strategic uses.

86. Easterbrook, The Limits of Antitrust, 63 TEx. L. REv. 1 (1984). 


\section{APPENDix}

In this appendix, we derive the optimal stipulated damage provision between a risk-neutral buyer and seller. The privately optimal choice of contract terms is that which maximizes the expected joint profits of the transactors, subject to the buyer's ex post decision of whether to perform the contract. Using the notation in the text, the buyer breaches whenever $v-p_{e}$ $-\delta>v-p$. The seller, in turn, receives $p-c$ if the contract is performed and $\delta$ if the buyer breaches. Since the buyer will switch only if $p_{e} \leq p-\delta$, and it will be in the entrant's interest to enter only if $p_{e} \geq s(\theta)$, the probability of breach is $\operatorname{Pr}[s(\theta)<p-\delta]$.

Suppose that the price received by the entrant is ultimately a matter of negotiation and falls somewhere between $p-\delta$ and $s(\theta)$. Then letting $\alpha$ characterize the outcome of those negotiations, the entrant's price can be written as $p_{e}=\alpha(p-\delta)+(1-\alpha) s(\theta)$, where $\alpha \epsilon[0,1]$ and may be thought of as a parameter reflecting the bargaining strength of the entrant relative to the buyer. If $\alpha=1$, the entrant has all the bargaining power and $p_{e}=p-\delta$; if $\alpha$ $=0$, the buyer has all of the bargaining power and $p_{e}=s(\theta)$. Letting $P$ represent the probability of breach, the incumbent seller's expected profits would be

$$
\pi_{S}=(1-P)(p-c)+P \delta
$$

and the buyer's

$$
\pi_{B}=(1-P)(v-p)+\int_{0}^{p-\delta}\left(v-p_{e}-\delta\right) P^{\prime} d s(\theta)
$$

Maximizing the sum of these two expressions with respect to $\delta$ yields the following first-order condition:

$$
\frac{\partial(\pi B+\pi S)}{\partial \delta}=P^{\prime}(\delta-p+c)-\alpha P=0 .
$$

Rewriting this expression yields $\delta=p-c+\frac{\alpha P}{p^{\prime}}$.

In other words, when $\alpha=1$ and the entrant is able to extract all the rents from entry (the Aghion-Bolton assumption), the optimal stipulated damage between the parties exceeds the lost-profit level. When $\alpha=0$ and the entrant is unable to charge a price above opportunity cost (as in the efficient breach model), the optimal penalty reduces to $\delta=p-c$, the ex post efficient level. 
